\title{
Efektivitas Implementasi Advice Planning di Perkotaan Banyuwangi
}

\author{
Ditya Destratianto dan Retno Widodo Dwi Pramono \\ Magister Perencanaan Wilayah dan Kota, Fakultas Teknik \\ Universitas Gadjah Mada \\ e-mail: dityadestratianto2018@mail.ugm.ac.id
}

\begin{abstract}
Abstrak-Advice Planning merupakan salah satu teknik instrumen preventif dalam pengendalian pembangunan lahan (development control/regulation) selain zonasi dan pemberian izin bangunan, yang digunakan di Kabupaten Banyuwangi. Alat ini berisi informasi dan ketentuan mengenai ketentuan teknis peruntukan lahan dan ketentuan umum peraturan zonasi untuk izin pemanfaatan ruang sesuai dengan fungsi kawasan berdasarkan rencana tata ruang yang dituangkan ke dalam bentuk peta. Ketentuan-ketentuan didalam advice planning seringkali tidak diimplementasikan di lapangan, terlebih lagi dengan adanya peningkatan jumlah pembangunan di Perkotaan Banyuwangi dalam kurun waktu 5 tahun terakhir yang tidak diimbangi dengan pengawasan yang cukup di lapangan. Tujuan dari penelitian ini adalah untuk mengukur seberapa besar efektivitas implementasi advice planning di perkotaan Banyuwangi. Penelitian ini menggunakan metode deduktif kuantitatif dengan penilaian realisasi komponen advice planning di lapangan. Data berupa data primer hasil observasi, wawancara dengan stakeholder dan dokumentasi, sedangkan data sekunder diperoleh dari studi pustaka dan data dinas terkait. Hasil penelitian menunjukkan bahwa efektivitas implementasi advice planning di perkotaan Banyuwangi masih rendah, yang disebabkan oleh belum terlaksananya seluruh komponen dalam ketentuan advice planning di lapangan, terutama komponen dalam aspek ketentuan teknis peruntukan ruang dan zonasi, seperti koefisien dasar bangunan, garis sempadan bangunan, penyediaan saluran drainase maupun saluran limbah.
\end{abstract}

Kata Kunci-Advice planning, Pengendalian Pemanfaatan Ruang, Perkotaan Banyuwangi

\section{PENDAHULUAN}

$\mathrm{P}$ ERKEMBANGAN kota yang sangat pesat akan membawa konsekuensi pada peningkatan akan permintaan lahan untuk berbagai kegiatan usaha maupun permukiman. Pengembangan permukiman umumnya menggunakan lahan yang belum terbangun, baik berupa sawah, tegalan atau lahan kosong lainnya. Pada kawasan lain, yaitu pada kawasan terbangun, terutama pada sekitar lokasi yang strategis, terjadi perubahan guna lahan secara besar-besaran dari kegiatan yang kurang produktif menjadi kegiatan yang lebih produktif. Kegiatan semacam ini banyak dijumpai pada kota-kota besar dunia. Beberapa kota di dunia menggunakan instrumen penataan ruang perkotaan yang salah satunya melalui pengendalian penggunaan lahan seperti perencanaan, zoning dan berbagai instrumen pengendali lainnya untuk mengantisipasi perkembangan guna lahan yang semakin pesat akhir-akhir ini [1]. Di Indonesia sendiri, berdasarkan Undang-undang Nomor 26 Tahun 2007 tentang Penataan Ruang dan Peraturan Pemerintah Nomor 15 Tahun 2010 tentang Penyelenggaraan Penataan Ruang, pengendalian pemanfaatan ruang merupakan bagian yang tidak terpisahkan dari proses penataan ruang.

Advice Planning merupakan salah satu teknik instrumen preventif dalam pengendalian pembangunan lahan (development control/regulation) selain zonasi dan pemberian izin bangunan, yang digunakan di Kabupaten Banyuwangi. Alat ini berisi informasi dan ketentuan mengenai ketentuan teknis peruntukan lahan dan ketentuan umum peraturan zonasi untuk izin pemanfaatan ruang sesuai dengan fungsi kawasan berdasarkan rencana tata ruang yang dituangkan ke dalam bentuk peta.

Setelah dikeluarkannya Peraturan Daerah Kabupaten Banyuwangi nomor 8 Tahun 2012 tentang Rencana Tata Ruang Wilayah Kabupaten Banyuwangi Tahun 2012-2032 yang mewajibkan setiap bangunan yang didirikan dilengkapi dengan Advice planning, Pemerintah Daerah Kabupaten Banyuwangi berangsur-angsur mulai menerapkan aturan tersebut, baik untuk pertokoan, perumahan, maupun kegiatan usaha lainnya. Namun, dalam implementasinya di lapangan, pengendalian pembangunan di Perkotaan Banyuwangi tidak berjalan secara efektif dan efisien, dan mengindikasikan munculnya beberapa permasalahan/penyimpangan, seperti :

1. Kecenderungan penyediaan fasilitas dan jaringan utilitas publik yang minim, misalnya RTH (Ruang Terbuka Hijau), TPU (Tempat Pemakaman Umum), dan fasilitas umum di perumahan;

2. Mengubah peruntukan persil yang seharusnya dibangun sebagai prasarana lingkungan, utilitas umum, fasilitas umum, atau fasilitas sosial ternyata telah dibangun ruko atau rumah pada saat perumahan tersebut telah terjual beberapa unit;

3. Ada beberapa kawasan yang seharusnya digunakan untuk daerah pertanian ternyata telah menjadi daerah permukiman dan pertokoan; dan

4. Banyak pelanggaran pemanfaatan ruang yang tidak sesuai dengan peruntukannya dan bangunan yang melanggar GSB (Garis Sempadan Bangunan), GSJ (Garis Sempadan Jalan), dan KDB (Koefisien Dasar Bangunan).

Penelitian-penelitian yang telah ada juga berorientasi terhadap aspek perizinan dalam pengendalian pemanfaatan ruang. Penelitian Muhajirin lebih berfokus kepada IMB (Izin Mendirikan Bangunan) [2]. Hal serupa juga dibahas oleh Sayogo (2008) yang melakukan evaluasi terhadap IMB (Izin Mendirikan Bangunan) sebagai instrument pengendalian pemanfaatan lahan [3]. Mengidentifikasi faktor-faktor yang mempengaruhi implementasi advice planning dalam perspektif good governance, namun hanya berfokus pada pembangunan perumahan saja [4]. Sedangkan 
Kautsary (2019) membahas kualitas instrumen pengendalian pemanfaatan ruang berdasarkan kelengkapan materi ketentuan umum peraturan zonasi yang ada [5].

Berbagai problematika yang telah dibahas terkait implementasi perizinan dalam pengendalian pemanfaatan ruang menjadi cukup menarik untuk dibahas lebih lanjut, terutama di perkotaan Banyuwangi. Sebagai bagian dari praktek perencanaan, mengevaluasi suatu kebijakan yang sudah berjalan sangat penting untuk dilakukan, yaitu : Undang-undang Nomor 26 Tahun 2007 tentang Penataan Ruang dan Peraturan Pemerintah Nomor 15 Tahun 2010 tentang Penyelenggaraan Penataan Ruang, apalagi tingkat pertumbuhan dan investasi yang masuk ke Kabupaten Banyuwangi sangat pesat dalam 5 tahun terakhir. Namun, hingga saat ini, belum pernah dilakukan evaluasi terhadap efektivitas advice planning terhadap pemanfaatan lahan di perkotaan Banyuwangi, baik oleh pemerintah daerah atau lembaga lain, sehingga penelitian ini dipandang perlu dilakukan. Penelitian ini bertujuan untuk mengukur seberapa besar efektivitas implementasi advice planning di perkotaan Banyuwangi.

\section{METODE PENELITIAN}

Penelitian ini berlokasi di perkotaan Banyuwangi, yang memiliki luas wilayah 7.953 Hektar atau $79,53 \mathrm{~km}^{2}$. Wilayah perkotaan Banyuwangi terbagi menjadi 5 Kecamatan , yaitu Kecamatan Banyuwangi, Giri, Glagah, Kabat, dan Kalipuro. Pemilihan lokasi ini sebagai sampel lokasi penelitian karena telah memiliki peraturan daerah terkait pemanfaatan ruang.

Pendekatan yang digunakan adalah pendekatan deduktif kuantitatif. Data terdiri 2 (dua) data utama, yaitu data primer dan data sekunder. Data primer yang terdiri atas data observasi yang bertujuan untuk menilai realisasi komponen advice planning di lapangan, wawancara dengan stakeholder yang terkait, dan dokumentasi sebagai alat bantu untuk keperluan penelitian untuk menghasilkan data deskriptif. Selanjutnya data sekunder, terdiri atas data hasil studi pustaka dan data informasi dari dinas terkait.

Teknik pengambilan sampel pada penelitian ini terbagi menjadi 2 (dua), yaitu sampel random untuk pemilihan kuantitatif guna observasi lapangan, yaitu pemohon yang telah mengajukan permohonan advice planning, dan sampel bertujuan untuk stakeholder terkait, yang terdiri dari unsur pemerintah daerah dan pemohon advice planning.

Tahapan yang dilakukan dalam kajian ini, pertama adalah mengidentifikasi ketentuan umum peraturan zonasi dalam Peraturan Daerah Kabupaten Banyuwangi Nomor 6 Tahun 2016 tentang Rencana Tata Ruang Kawasan Strategis Pelabuhan Ketapang Banyuwangi dan Rencana Detail Tata Ruang Bagian Wilayah Perkotaan Banyuwangi Tahun 20162035 yang tertuang dalam advice planning yang telah diterbitkan. Kedua mengobservasi masing-masing lokasi permohonan advice planning untuk mengidentifikasi realisasi komponen advice planning di lapangan. Ketiga, menganalisis perbandingan antara ketentuan dalam advice planning dengan realisasi di lapangan, dengan melakukan bobot penilaian dari masing-masing komponen advice planning, yaitu 0 (nol) tidak dilaksanakan dan 1 (satu) dilaksanakan oleh pemohon, dimana kategorisasi data tingkat efektivitas menjadi 2 kategori, tinggi dan rendah, dengan ketentuan tingkat efektivitas tinggi apabila nilai persentase komponen (nilai realisasi komponen di lapangan, yaitu 1-13, dibagi dengan total jumlah komponen, yaitu 13 komponen, kemudian dikalikan 100) pelaksanaan advice planning $\geq 50 \%$ dan efektivitas rendah apabila nilai persentase komponen pelaksanaan advice planning $<50 \%$.

\section{HASIL DAN DISKUSI}

\section{A. Karakteristik Pemohon Advice planning}

Hasil analisis dari data sekunder yang diperoleh dari instansi terkait, yaitu data permohonan advice planning di perkotaan Banyuwangi tahun 2018 dari Dinas PU Cipta Karya dan Penataan Ruang Kabupaten Banyuwangi. Sebaran lokasi permohonan advice planning di perkotaan Banyuwangi dapat dilihat pada gambar 1 berikut.

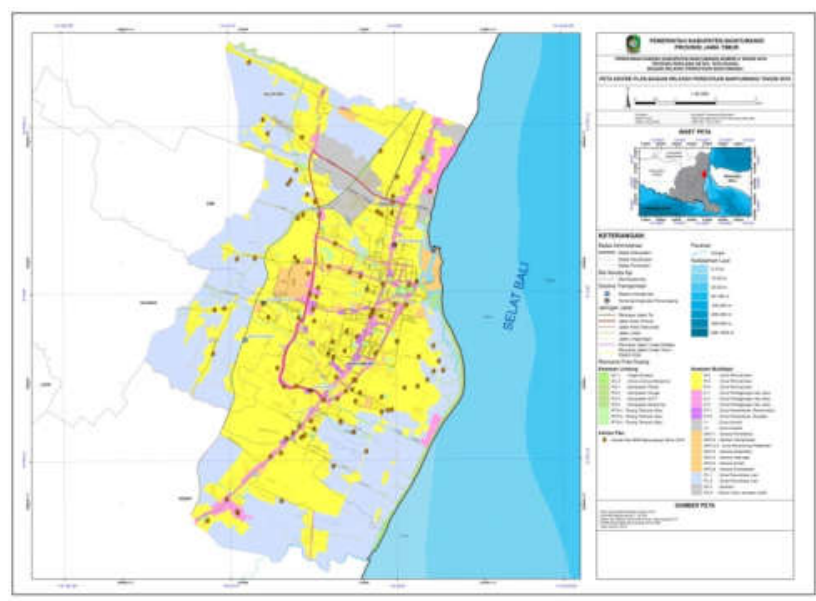

Gambar 1. Peta Sebaran Permohonan Advice planning di Perkotaan Banyuwangi Tahun 2018 [6]

Berdasarkan kuesioner yang disebarkan pada 73 responden, maka diperoleh data sekunder yang dikuatkan dengan data primer, meliputi jumlah pemohon advice planning, jenis kelamin, latar belakang, jenis usaha pemohon, lokasi pembangunan dan luas usaha. Responden sebagian besar merupakan laki-laki (75,34 \%), karena sebagai pimpinan atau pemilik usaha dan mengetahui kondisi pelaksanaan proses pembangunan. Pemohon advice planning dapat dibagi menjadi 2 (dua) latar belakang, yaitu perorangan $(50,68 \%)$ dan badan usaha (49,32\%).

Jumlah permohonan advice planning yang pernah diajukan sebagian besar hanya satu kali saja atau sebesar 94,52 \% dari 73 pemohon, sehingga dapat dikatakan bahwa sebagian besar pemohon masih mempunyai pengalaman yang sedikit mengajukan permohonan advice planning. Sedangkan untuk jenis usaha, yang paling banyak adalah cluster dan perumahan, yaitu sebanyak 14 advice planning $(20,55 \%)$, dan yang paling sedikit adalah tambak, hanya sebanyak 2 advice planning (2,74\%).

Jarak dari lokasi permohonan ke pusat kota cukup bervariasi antara $0,5-7,5 \mathrm{~km}$. Mayoritas lokasi usaha berada pada jarak 1,5 - $3 \mathrm{~km}$ dari pusat kota, yang berada di Kecamatan Banyuwangi dan sekitarnya, yang merupakan kecamatan yang berada dekat dengan pusat kota. Hal ini dikarenakan pemohon mempertimbangkan lokasi usaha 
yang dekat dengan pusat kota akan mempunyai akses dan fasilitas yang baik.

Adapun luas usaha yang diajukan oleh pemohon advice planning sebagian besar antara $500 \mathrm{~m}^{2}-5.000 \mathrm{~m}^{2}$, yaitu sebesar $41,10 \%$. Hal ini menandakan bahwa pemohon advice planning di perkotaan Banyuwangi termasuk dalam pembangunan skala kecil/menengah. Distribusi frekuensi karakteristik permohonan advice planning dapat dapat dilihat pada tabel 1 berikut.

Tabel 1.

Distribusi Frekuensi Karakteristik Permohonan Advice Planning di Perkotaan Banyuwangi Tahun 2018

\begin{tabular}{|c|c|c|c|c|}
\hline No. & & Karakteristik & Jumlah & Persentase $(\%)$ \\
\hline \multirow[t]{3}{*}{1.} & \multirow{3}{*}{$\begin{array}{l}\text { Jenis } \\
\text { Kelamin }\end{array}$} & Laki-Laki & 55 & 75,34 \\
\hline & & Perempuan & 18 & 24,66 \\
\hline & & Total & 73 & 100,00 \\
\hline \multirow[t]{3}{*}{2.} & \multirow{3}{*}{$\begin{array}{l}\text { Latar } \\
\text { Belakang }\end{array}$} & Perorangan & 37 & 50,68 \\
\hline & & Badan usaha & 36 & 49,32 \\
\hline & & Total & 73 & 100,00 \\
\hline \multirow[t]{10}{*}{3.} & \multirow[t]{10}{*}{$\begin{array}{l}\text { Jenis } \\
\text { Usaha }\end{array}$} & $\begin{array}{l}\text { Homestay dan } \\
\text { Guesthouse }\end{array}$ & 5 & 6,85 \\
\hline & & Tambak & 2 & 2,74 \\
\hline & & Hotel dan Karaoke & 3 & 4,11 \\
\hline & & Rumah Makan & 6 & 8,22 \\
\hline & & Toko & 8 & 10,96 \\
\hline & & $\begin{array}{l}\text { Kantor dan Tempat } \\
\text { Usaha }\end{array}$ & 11 & 15,07 \\
\hline & & $\begin{array}{l}\text { Sarana Pelayanan } \\
\text { Umum }\end{array}$ & 10 & 13,70 \\
\hline & & Rumah Kost & 13 & 17,81 \\
\hline & & $\begin{array}{l}\text { Cluster dan } \\
\text { Perumahan }\end{array}$ & 15 & 20,55 \\
\hline & & Total & 73 & 100,00 \\
\hline \multirow[t]{6}{*}{4.} & \multirow[t]{6}{*}{ Lokasi } & $\begin{array}{l}\text { Kecamatan } \\
\text { Banyuwangi }\end{array}$ & 43 & 58,90 \\
\hline & & Kecamatan Giri & 16 & 21,92 \\
\hline & & Kecamatan Glagah & 4 & 5,48 \\
\hline & & Kecamatan Kabat & 6 & 8,22 \\
\hline & & Kecamatan Kalipuro & 4 & 5,48 \\
\hline & & Total & 73 & 100,00 \\
\hline \multirow[t]{5}{*}{5.} & \multirow{5}{*}{$\begin{array}{l}\text { Jarak } \\
\text { dengan } \\
\text { pusat } \\
\text { kota }\end{array}$} & $<1,5 \mathrm{~km}$ & 22 & 30,14 \\
\hline & & $1,5 \mathrm{~km}-3 \mathrm{~km}$ & 34 & 46,58 \\
\hline & & $3 \mathrm{~km}-4,5 \mathrm{~km}$ & 12 & 16,44 \\
\hline & & $>4,5 \mathrm{~km}$ & 5 & 6,85 \\
\hline & & Total & 73 & 100,00 \\
\hline \multirow[t]{5}{*}{6.} & \multirow{5}{*}{$\begin{array}{l}\text { Luas } \\
\text { Usaha }\end{array}$} & $<500 \mathrm{~m}^{2}$ & 21 & 28,77 \\
\hline & & $500 \mathrm{~m}^{2}-5.000 \mathrm{~m}^{2}$ & 30 & 41,10 \\
\hline & & $5.000 \mathrm{~m}^{2}-10.000 \mathrm{~m}^{2}$ & 6 & 8,22 \\
\hline & & $>10.000 \mathrm{~m}^{2}$ & 16 & 21,92 \\
\hline & & Total & 73 & 100,00 \\
\hline
\end{tabular}

\section{B. Efektivitas Implementasi Advice planning}

Efektivitas adalah jawaban dari pertanyaan apakah hasil yang diinginkan telah tercapai. selalu diukur dari unit produk atau layanan atau nilai moneternya [7]. Di penelitian ini, aspek yang diukur dalam penilaian efektivitas implementasi advice planning dilakukan berdasarkan perbandingan antara komponen yang ada dalam ketentuan mengenai advice planning yang diterbitkan oleh instansi terkait, yaitu ketentuan teknis pengembangan lahan dan ketentuan umum peraturan zonasi, peta advice planning yang dikeluarkan, serta ketentuan umum atau administratif lainnya untuk memberikan arahan dan pedoman bagi pembangunan dengan hasil observasi di lapangan. Efektivitas implementasi advice planning berdasarkan komponennya dapat dilihat pada tabel 2.
Dari hasil penilaian terhadap 13 komponen advice planning pada tabel 2, efektivitas implementasi tersebut dikelompokkan menjadi dua kelompok kriteria, yaitu rendah apabila efektivitas implementasi komponennya $<50 \%$, dan tinggi apabila efektivitas implementasi komponennya $>50$ $\%$. Komponen advice planning yang termasuk dalam kriteria tinggi dan memperoleh nilai tertinggi, meliputi 1) Kesesuaian peruntukan dengan rencana tata ruang $(97,26$ \%), 2) Fungsi bangunan yang dapat dibangun (90,41 \%), dan 3) Koefisien lantai bangunan (86,3 \%). Sedangkan untuk komponen advice planning yang termasuk dalam kriteria rendah dan memperoleh nilai terendah, meliputi 1) Kesediaan membangun setelah IMB (Izin Mendirikan Bangunan) terbit, 2) Koefisien dasar bangunan (2,74\%), dan 3) Garis sempadan bangunan $(8,22 \%)$. Urutan komponan efektivitas implementasi advice planning di perkotaan Banyuwangi dapat dilihat pada gambar 2 berikut.

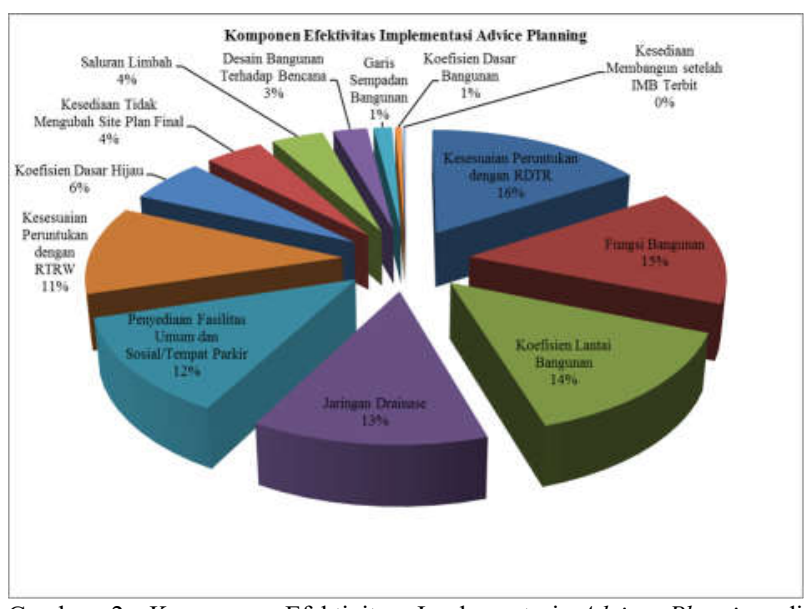

Gambar 2. Komponen Efektivitas Implementasi Advice Planning di Perkotaan Banyuwangi Tahun 2018

Hasil wawancara yang diperoleh dari instansi terkait memperkuat hasil analisis yang telah dilakukan pada tabel 2 , bahwa komponen tersebut hanya dipenuhi pemohon sebagai formalitas semata untuk memperoleh advice planning dan IMB (Izin Mendirikan Bangunan) untuk pembangunan dan tidak mematuhi sebagian besar ketentuan teknis advice planning, karena persepsi pemohon selama ini adalah advice planning bukan merupakan bagian dari produk perizinan, yang sifatnya hanya rekomendasi yang berisikan informasi peruntukan lahan dan ketentuan umum peraturan zonasi. Masyarakat dan swasta tidak menyadari akan pentingnya memedomani advice planning yang diterbitkan, terutama yang termasuk pada pengembang/pengusaha kecil, kebanyakan tidak menyediakan ruang terbuka hijau dan fasilitas umum maupun sosial lainnya. Padahal, sebelum mengajukan advice planning, pemohon diwajibkan untuk melengkapi persyaratan seperti perjanjian untuk tidak mengubah site plan final serta menyerahkan fasilitas umum dan sosial. 
Tabel 2.

Efektivitas Implementasi Advice Planning berdasarkan Komponennya

\begin{tabular}{|c|c|c|c|c|c|c|c|}
\hline No & $\begin{array}{c}\text { Komponen } \\
A P \\
\end{array}$ & \multicolumn{2}{|c|}{ Standar dan Pedoman yang Digunakan } & $\begin{array}{c}\text { Realisasi } \\
\mathrm{N}=73\end{array}$ & $\begin{array}{c}\text { Persentase } \\
(\%)\end{array}$ & $\begin{array}{c}\text { Efektivitas } \\
\text { Implementasi }\end{array}$ & Keterangan \\
\hline \multicolumn{8}{|c|}{ Ketentuan Peraturan Zonasi } \\
\hline 1. & $\begin{array}{l}\text { Kesesuaian } \\
\text { peruntukan } \\
\text { dengan } \\
\text { RTRW }\end{array}$ & Rencana pola ruang dalam RTRW & & 50 & 68,49 & Tinggi & $\begin{array}{l}50 \text { lokasi } \\
\text { telah sesuai } \\
\text { peruntukann } \\
\text { ya dengan } \\
\text { RTRW (> } \\
50 \% \text { dari } \\
\text { total } \\
\text { sampel) } \\
\end{array}$ \\
\hline 2. & $\begin{array}{l}\text { Kesesuaian } \\
\text { peruntukan } \\
\text { dengan } \\
\text { RDTR }\end{array}$ & Rencana pola ruang dalam RDTR & & 71 & 97,26 & Tinggi & $\begin{array}{l}71 \text { lokasi } \\
\text { telah sesuai } \\
\text { peruntukann } \\
\text { ya dengan } \\
\text { RDTR ( }>50 \\
\% \text { dari total } \\
\text { sampel) }\end{array}$ \\
\hline 3. & $\begin{array}{l}\text { Fungsi } \\
\text { bangunan } \\
\text { yang dapat } \\
\text { dibangun }\end{array}$ & Peraturan Zonasi RDTR & & 66 & 90,41 & Tinggi & $\begin{array}{l}66 \text { lokasi } \\
\text { telah sesuai } \\
\text { dengan } \\
\text { fungsi } \\
\text { bangunan } \\
\text { yang dapat } \\
\text { dibangun }(> \\
50 \% \text { dari } \\
\text { total } \\
\text { sampel) } \\
\end{array}$ \\
\hline 4. & $\begin{array}{l}\text { Koefisen } \\
\text { Dasar } \\
\text { Bangunan }\end{array}$ & $\begin{array}{l}\text { - } \text { Perumahan kepadatan tinggi }=75 \% \\
\text { - Perumahan kepadatan sedang }=60 \% \\
\text { - Perumahan kepadatan rendah }=30 \% \\
\text { - } \text { Perdagangan dan jasa tunggal }=60 \% \\
\text { - } \text { Perdagangan dan jasa deret }=60 \% \\
\text { - Perkantoran pemerintah }=50 \% \\
\text { - } \text { Perkantoran swasta }=70 \% \\
\end{array}$ & $\begin{array}{l}\text { - Sarana pelayanan umum } \\
\text { pendidikan }=50 \% \\
\text { - Sarana pelayanan umum } \\
\text { kesehatan }=60 \% \\
\text { - Sarana pelayanan umum } \\
\text { olahraga }=50 \% \\
\text { - Pertanian }=5 \%\end{array}$ & 2 & 2,74 & Rendah & $\begin{array}{l}\text { Hanya } 2 \\
\text { lokasi yang } \\
\text { sesuai } \\
\text { dengan } \\
\text { standar } \\
\text { KDB }(<50 \\
\% \text { dari total } \\
\text { sampel }) \\
\end{array}$ \\
\hline 5. & $\begin{array}{l}\text { Koefisen } \\
\text { Lantai } \\
\text { Bangunan }\end{array}$ & $\begin{array}{l}\text { - Perumahan kepadatan tinggi }=150 \% \\
\text { - Perumahan kepadatan sedang }=120 \\
\% \\
\text { - Perumahan kepadatan rendah }=120 \\
\quad \% \\
\text { - Perdagangan dan jasa tunggal }=800 \\
\% \\
\text { - Perdagangan dan jasa deret }=300 \% \\
\text { - Perkantoran pemerintah }=250 \% \\
\text { - Perkantoran swasta }=350 \% \\
\end{array}$ & $\begin{array}{l}\text { - Sarana pelayanan umum } \\
\text { pendidikan }=150 \% \\
\text { - Sarana pelayanan umum } \\
\text { kesehatan }=150 \% \\
\text { - Sarana pelayanan umum } \\
\text { olahraga }=150 \% \\
\text { - Pertanian }=5 \%\end{array}$ & 63 & 86,3 & Tinggi & $\begin{array}{l}63 \text { lokasi } \\
\text { telah sesuai } \\
\text { dengan } \\
\text { standar } \\
\text { KLB }(>50 \\
\% \text { dari total } \\
\text { sampel })\end{array}$ \\
\hline 6. & $\begin{array}{l}\text { Koefisien } \\
\text { Dasar } \\
\text { Hijau }\end{array}$ & $\begin{array}{l}\text { - Perumahan kepadatan tinggi }=25 \% \\
\text { - Perumahan kepadatan sedang }=40 \% \\
\text { - Perumahan kepadatan rendah }=70 \% \\
\text { - Perdagangan dan jasa tunggal }=40 \% \\
\text { - Perdagangan dan jasa deret }=40 \% \\
\text { - Perkantoran pemerintah }=50 \% \\
\text { - Perkantoran swasta }=30 \%\end{array}$ & $\begin{array}{l}\text { - Sarana pelayanan umum } \\
\text { pendidikan }=50 \% \\
\text { - Sarana pelayanan umum } \\
\text { kesehatan }=40 \% \\
\text { - Sarana pelayanan umum } \\
\text { olahraga }=50 \% \\
\text { - Pertanian }=95 \%\end{array}$ & 25 & 34,25 & Rendah & $\begin{array}{l}\text { Hanya } 25 \\
\text { lokasi yang } \\
\text { sesuai } \\
\text { dengan } \\
\text { standar } \\
\text { KDH }(<50 \\
\% \text { dari total } \\
\text { sampel }) \\
\end{array}$ \\
\hline 7 & $\begin{array}{l}\text { Garis } \\
\text { Sempadan } \\
\text { Bangunan }\end{array}$ & $\begin{array}{l}\text { - Perumahan kepadatan tinggi }=3 \mathrm{~m} \\
\text { - Perumahan kepadatan sedang }=5 \mathrm{~m} \\
\text { - Perumahan kepadatan rendah }=6 \mathrm{~m} \\
\text { - Perdagangan dan jasa tunggal }=8 \mathrm{~m} \\
\text { - Perdagangan dan jasa deret }=5 \mathrm{~m} \\
\text { - Perkantoran pemerintah }=8 \mathrm{~m} \\
\text { - Perkantoran swasta }=6 \mathrm{~m}\end{array}$ & $\begin{array}{l}\text { - Sarana pelayanan umum } \\
\text { pendidikan }=6 \mathrm{~m} \\
\text { - Sarana pelayanan umum } \\
\text { kesehatan }=6 \mathrm{~m} \\
\text { - Sarana pelayanan umum } \\
\text { olahraga }=5 \mathrm{~m} \\
\text { - Pertanian }=6 \mathrm{~m}\end{array}$ & 6 & 8,22 & Rendah & $\begin{array}{l}\text { Hanya } 6 \\
\text { lokasi yang } \\
\text { sesuai } \\
\text { dengan } \\
\text { standar } \\
\text { GSB }(<50 \\
\% \text { dari total } \\
\text { sampel }) \\
\end{array}$ \\
\hline \multicolumn{8}{|c|}{ Ketentuan Teknis Peruntukan Ruang } \\
\hline 8. & $\begin{array}{l}\text { Desain } \\
\text { bangunan } \\
\text { terhadap } \\
\text { bencana }\end{array}$ & Standart minimal prasarana dan sarana & & 11 & 15,07 & Rendah & $\begin{array}{l}\text { Hanya } 11 \\
\text { lokasi yang } \\
\text { sesuai } \\
\text { dengan } \\
\text { standar } \\
\text { desain } \\
\text { bangunan } \\
\text { terhadap } \\
\text { bencana (< } \\
50 \% \text { dari } \\
\text { total } \\
\text { sampel) }\end{array}$ \\
\hline
\end{tabular}




\begin{tabular}{|c|c|c|c|c|c|c|}
\hline No & $\begin{array}{c}\text { Komponen } \\
A P \\
\end{array}$ & Standar dan Pedoman yang Digunakan & $\begin{array}{c}\text { Realisasi } \\
\mathrm{N}=73\end{array}$ & $\begin{array}{c}\text { Persentase } \\
(\%)\end{array}$ & $\begin{array}{c}\text { Efektivitas } \\
\text { Implementasi }\end{array}$ & Keterangan \\
\hline 9. & $\begin{array}{l}\text { Penyediaan } \\
\text { jaringan } \\
\text { drainase }\end{array}$ & Terkoneksi dengan jaringan kota & 56 & 76,71 & Tinggi & $\begin{array}{l}56 \text { lokasi } \\
\text { telah } \\
\text { menyediaka } \\
\text { n jaringan } \\
\text { drainase } \\
\text { yang } \\
\text { terkoneksi } \\
\text { dengan } \\
\text { jaringan } \\
\text { kota ( }>50 \\
\% \text { dari total } \\
\text { sampel) }\end{array}$ \\
\hline 10. & $\begin{array}{l}\text { Penyediaan } \\
\text { saluran } \\
\text { limbah }\end{array}$ & Disyaratkan oleh Dinas Lingkungan Hidup & 17 & 23,29 & Rendah & $\begin{array}{l}\text { Hanya } 17 \\
\text { lokasi yang } \\
\text { telah } \\
\text { menyediaka } \\
\text { n saluran } \\
\text { limbah } \\
\text { sesuai } \\
\text { dengan } \\
\text { yang } \\
\text { disyaratkan } \\
(<50 \% \text { dari } \\
\text { total } \\
\text { sampel) }\end{array}$ \\
\hline 11. & $\begin{array}{l}\text { Penyediaan } \\
\text { fasilitas } \\
\text { umum dan } \\
\text { sosial/peny } \\
\text { ediaan } \\
\text { lahan } \\
\text { parkir }\end{array}$ & Standart minimal prasarana dan sarana & 55 & 75,34 & Tinggi & $\begin{array}{l}55 \text { lokasi } \\
\text { telah } \\
\text { menyediaka } \\
\mathrm{n} \text { fasilitas } \\
\text { umum dan } \\
\text { sosial/lahan } \\
\text { parkir yang } \\
\text { sesuai } \\
\text { dengan } \\
\text { standar } \\
\text { minimal (> } \\
50 \% \text { dari } \\
\text { total } \\
\text { sampel) } \\
\end{array}$ \\
\hline \multicolumn{7}{|c|}{ Ketentuan Umum/Administrasi } \\
\hline 12. & $\begin{array}{l}\text { Kesediaan } \\
\text { tidak } \\
\text { mengubah } \\
\text { siteplan } \\
\text { final }\end{array}$ & Persyaratan administrasi & 19 & 26,03 & Rendah & $\begin{array}{l}\text { Hanya } 19 \\
\text { lokasi yang } \\
\text { tidak } \\
\text { mengubah } \\
\text { siteplan } \\
\text { final sesuai } \\
\text { dengan } \\
\text { yang } \\
\text { disyaratkan } \\
(<50 \% \text { dari } \\
\text { total } \\
\text { sampel })\end{array}$ \\
\hline 13. & $\begin{array}{l}\text { Kesediaan } \\
\text { membangu } \\
\text { n setelah } \\
\text { IMB terbit }\end{array}$ & Persyaratan administrasi & 1 & 1,37 & Rendah & $\begin{array}{l}\text { Hanya } 1 \\
\text { lokasi yang } \\
\text { melakukan } \\
\text { pembangun } \\
\text { an setelah } \\
\text { IMB terbit, } \\
\text { sesuai } \\
\text { dengan } \\
\text { yang } \\
\text { disyaratkan } \\
(<50 \% \text { dari } \\
\text { total } \\
\text { sampel) }\end{array}$ \\
\hline
\end{tabular}

Implementasi pada prinsipnya merupakan upaya sebuah kebijakan untuk dapat mencapai tujuannya [8]. Akan tetapi dalam pelaksanaan implementasi tersebut, terdapat beberapa permasalahan yang muncul di lapangan, sehingga tujuan yang diharapkan dalam penerbitan advice planning tidak dapat terwujud. Permasalahan tersebut (rendahnya nilai komponen efektivitas implementasi advice planning di lapangan) antara lain disebabkan oleh masih rendahnya tingkat pemahaman masyarakat/pemohon terhadap fungsi advice planning, yang diakui oleh pemerintah daerah bahwa selama ini kurang melakukan sosialisasi dan terbatasnya undangan sosialisasi setiap tahunnya, sehingga informasi yang masyarakat peroleh masih terbatas dan tidak lengkap, serta masih banyak ditemukan penyimpangan di lapangan 
seperti melakukan pembangunan terlebih dulu dan mengurus izin belakangan (komponen dengan nilai terendah). Hal ini sejalan dengan penelitian bahwa masyarakat memiliki karakteristik dimana kebanyakan mereka tidak mengetahui prosedur dan ketentuan yang berlaku, sehingga mereka cenderung melakukan pembangunan yang tidak sesuai dengan arahan pemanfaatan ruang [9].

Hasil wawancara yang diperoleh dari pihak pemohon/masyarakat, bahwa salah satu penyebab rendahnya nilai komponen efektivitas implementasi advice planning di lapangan, yaitu pemerintah daerah kurang mempunyai komitmen dalam hal pengawasan dan penegakan hukum, sehingga menyulitkan dalam mengatur kualitas pembangunan perkotaan yang menjadi tujuan advice planning tersebut diterapkan. Kurangnya pengawasan yang dijalankan oleh pemerintah daerah dalam memastikan efektivitas implementasi advice planning di lapangan menyebabkan banyaknya bangunan yang tidak dibangun sesuai dengan standart minimal dalam advice planning. Responden berpendapat pengawasan dilakukan jika terjadi pelanggaran saja. Pemerintah Daerah Kabupaten Banyuwangi sendiri menjelaskan bahwa jadwal tim pengawasan untuk turun ke lapangan dan melakukan pengawasan adalah sebanyak 2-3 kali dalam satu minggu dan pengawasan yang dilakukan tidak hanya berfokus untuk advice planning saja, namun hingga IMB (Izin Mendirikan Bangunan). Jika di lapangan ada yang belum dapat diawasi, masalahnya terdapat pada keterbatasan sumberdaya manusia yang dimiliki selama ini.

Pelanggaran terhadap rencana tata ruang yang ada jarang sekali dikenai teguran, paksaan (enforcement), apalagi sanksi. Bagi yang mentaati peraturan dan rencana tata ruang juga tidak diberi penghargaan. Akibatnya, para pelaku pembangunan cenderung untuk membangun sesuai dengan kehendak dan kepentingan sendiri, mengabaikan kepentingan umum yang lebih luas. Dengan tidak adanya sistem insentif dan disinsentif, kecenderungan tersebut kian merebak dari waktu ke waktu [10]. Di perkotaan Banyuwangi, bentuk sanksi tertinggi yang pernah diterima oleh pemohon selama ini hanya sebatas peringatan lisan saja, dikarenakan belum melakukan pengurusan IMB (Izin Mendirikan Bangunan) dan telah melakukan pembangunan sebelum adanya IMB (Izin Mendirikan Bangunan).

Sebenarnya, dalam Peraturan Daerah Kabupaten Banyuwangi No. 9 Tahun 2014 tentang Bangunan Gedung telah dijelaskan bahwa masyarakat dapat melaporkan secara lisan dan atau tertulis kepada dinas terkait atas perbuatan setiap dan/atau badan yang dapat mengurangi dan atau mengganggu penyelenggaraan bangunan dan lingkungannya, namun karena kurangnya sosialisasi dari pemerintah dan kebanyakan masyarakat juga tidak mengetahui ketentuan tersebut, sehingga masyarakat terkesan tidak aktif dan terlibat dalam pengawasan di lapangan terkait dengan adanya pelanggaran-pelanggaran bangunan yang terjadi selama ini.

Berdasarkan hasil observasi lapangan dan data sekunder, diketahui bahwa jumlah pembangunan di perkotaan Banyuwangi dengan efektivitas implementasi rendah lebih besar daripada efektivitas implementasi tinggi, yaitu 45 dari 73 lokasi penelitian atau sebesar 61,64 \%. Dari ke-13 komponen yang ada, hanya 6 komponen advice planning yang termasuk dalam kriteria tinggi (bernilai $>50 \%$ dari total sampel), sedangkan 7 lainnya termasuk dalam kriteria rendah (bernilai $<50 \%$ dari total sampel). Nilai efektivitas implementasi rendah berkisar antara 2-6 dengan rata-rata 5,02 atau 38,63\% (didapatkan dari nilai realisasi lokasi yang memiliki efektivitas implementasi advice planning rendah dibagi dengan jumlah lokasi yang memiliki efektivitas implementasi advice planning rendah), sedangkan untuk nilai efektivitas implementasi tinggi berkisar antara 7-10 dengan rata-rata 7,71 atau 59,34 \% dari nilai 13 apabila seluruh komponen yang dinilai seharusnya terpenuhi. (didapatkan dari nilai realisasi lokasi yang memiliki efektivitas implementasi advice planning tinggi dibagi dengan jumlah lokasi yang memiliki efektivitas implementasi advice planning tinggi). Distribusi Frekuensi Efektivitas Implementasi Advice Planning dapat dilihat pada tabel 3 berikut.

Tabel 3.

Distribusi Frekuensi Efektivitas Implementasi Advice Planning

\begin{tabular}{cccccccc}
\hline \hline No. & $\begin{array}{c}\text { Efektivitas } \\
\text { Implement } \\
\text { asi }\end{array}$ & Nilai & $\begin{array}{c}\text { Rata- } \\
\text { rata } \\
(\%)\end{array}$ & $\begin{array}{c}\text { Nilai } \\
\text { Rata- } \\
\text { Rata }\end{array}$ & $\begin{array}{c}\text { Jumlah } \\
\text { Lokasi }\end{array}$ & $\begin{array}{c}\text { Persen } \\
\text { tase } \\
(\%)\end{array}$ & $\begin{array}{c}\text { Interpr } \\
\text { etasi }\end{array}$ \\
\hline 1. & $<50 \%$ & 7 & 38,63 & 5,02 & 45 & 61,64 & Rendah \\
\hline 2. & $>50 \%$ & 6 & 59,34 & 7,71 & 28 & 38,36 & Tinggi \\
\hline & Total & 13 & 46,58 & 6,05 & 73 & 100 & \\
\hline \hline
\end{tabular}

\section{KESIMPULAN/RINGKASAN}

Efektivitas implementasi advice planning di wilayah penelitian dapat dikategorikan rendah. Rendahnya efektivitas implementasi advice planning tersebut disebabkan oleh belum terlaksananya seluruh komponen dalam ketentuan advice planning di lapangan. Masih terdapat beberapa komponen, terutama komponen yang terdapat dalam aspek ketentuan teknis peruntukan ruang dan zonasi, seperti koefisien dasar bangunan, garis sempadan bangunan, koefisien dasar hijau, desain bangunan terhadap bencana, penyediaan saluran limbah, kesediaan tidak mengubah siteplan final, dan kesediaan membangun setelah IMB (Izin Mendirikan Bangunan) terbit. Dari 13 komponen ketentuan advice planning yang digunakan, hanya 6 komponen advice planning yang mempunyai efektivitas tinggi, yang ditandai dengan besarnya kesesuaian antara ketentuan advice planning yang dikeluarkan pemerintah daerah dengan praktek pembangunan di kawasan perkotaan, seperti peruntukan lokasi, fungsi bangunan yang dapat dibangun, dan koefisien lantai bangunan, yang secara umum telah diketahui dan mudah dilaksanakan oleh pemohon. Beberapa faktor yang mempengaruhi rendahnya efektivitas implementasi advice planning di perkotaan Banyuwangi diantaranya adalah :

1. Pemerintah kurang melakukan sosialisasi terkait prosedur pengurusan advice planning;

2. Tingkat pemahaman pemohon terhadap fungsi advice planning;

3. Komitmen pemohon yang masih rendah dalam menyediakan standart minimal infrastruktur yang telah ditetapkan;

4. Belum ada peraturan khusus terkait mekanisme pengawasan terkait implementasi advice planning di lapangan;

5. Masih rendahnya komitmen pemerintah daerah dalam mengendalikan kualitas pembangunan di perkotaan 
Banyuwangi, yang ditandai dengan kurangnya pengawasan yang dilakukan oleh pemerintah daerah untuk memastikan efektivitas implementasi advice planning di lapangan.

6. Kurangnya peran serta masyarakat dalam pengawasan pembangunan di lapangan.

Adapun saran yang diberikan kepada pemerintah daerah dan pemohon terkait dengan hasil penelitian yang telah dilakukan, antara lain :

1. Perlunya pelaksanaan sosialisasi mengenai peraturan dan prosedur administrasi maupun teknis yang lebih merata ke seluruh wilayah, yang menyangkut proses penerbitan advice planning.

2. Perlunya penyediaan informasi yang jelas dan memadai kepada pemohon dan disampaikan dengan baik sehingga mudah diakses oleh pemohon, disertai dengan pemaparan yang jelas terhadap fungsi dan tujuan penerbitan advice planning secara lebih konkrit dan dampak yang dapat ditimbulkan apabila tidak dilaksanakan oleh pemohon, sehingga pemohon lebih memahami substansi dan pentingnya penerbitan advice planning bagi pembangunan.

3. Perlu adanya mekanisme yang mengatur lebih tegas mengenai pengenaan sanksi, pemberian insentif dan disinsentif bagi pihak yang melanggar maupun yang taat terhadap pelaksanaan di lapangan sehingga bentuk penyimpangan yang terjadi dapat diminimalisir. Selain itu, perlu adanya mekanisme evaluasi yang dilakukan secara kontinu dengan melibatkan tim evaluasi yang berasal dari dinas terkait dan masyarakat sebagai pengawas eksternal terhadap advice planning yang telah diterbitkan untuk meningkatkan kualitas produk advice planning. Masyarakat juga dapat ikut menilai performa pemerintah daerah melalui pengadaan survey kepuasan masyarakat secara rutin tiap tahun.

4. Saran untuk penelitian selanjutnya yang memungkinkan, yaitu perlunya pengkajian dampak pelaksanaan advice planning bagi masyarakat dan lingkup wilayah yang lebih luas seperti Kabupaten.

\section{UCAPAN TERIMA KASIH}

Artikel ini hasil dari penelitian tesis di Magister Perencanaan Wilayah dan Kota, Fakultas Teknik, Universitas Gadjah Mada. Peneliti mengucapkan terimakasih kepada Pusat Pembinaan, Pendidikan dan Pelatihan Perencanaan Bappenas (Pusbindiklatren Bappenas) selaku pihak pemberi beasiswa. Ucapan terimakasih juga dipersembahkan kepada seluruh komunitas akademik Universitas Gadjah Mada, Pemerintah Daerah Kabupaten Banyuwangi, pihak swasta, dan pihak masyarakat yang telah membantu selesainya proses penelitian ini.

\section{DAFTAR PUSTAKA}

[1] H. Dunkerley, "Urban Land Use Policy: Issues and Opportunities," Oxford University Press, Washington (1983).

[2] Muhajirin, "Pengendalian Pembangunan Perumahan di Kawasan Bandung Utara: Perbandingan antara Kebijakan dan Realitas," Universitas Gadjah Mada, Yogyakarta (2000).
[3] D. Sayogo, "Evaluasi IMB sebagai Instrumen Pengendalian Pemanfaatan Lahan," Universitas Gadjah Mada, Yogyakarta (2008).

[4] E. Rilva, "Implementasi Advice Planning sebagai Instrumen Pengendalian Pembangunan dalam Perspektif Good Governance di Kota Payakumbuh," Universitas Gadjah Mada, Yogyakarta (2015).

[5] J. Kautsary, S. Shafira, "Kualitas Instrumen Pengendalian Pemanfaatan Ruang Berdasarkan Kelengkapan Materi Ketentuan Umum Peraturan Zonasi Rencana Tata Ruang Wilayah di Kabupaten Kendal,” Jurnal Planologi, Universitas Islam Sultan Agung Semarang, Vol. 16, No. 1 (2019, April) 1-15.

[6] BAPPEDA, "Laporan Akhir RDTR Bagian Wilayah Perkotaan Banyuwangi," Banyuwangi (2014).

[7] W. Dunn, "Analisis Kebijakan Publik," Gadjah Mada University Press, Yogyakarta (1994).

[8] R. Nakamura and F. Smallwood, "The Politics of Policy Implementation," St. Martin Press, New York (1980).

[9] Farmer, W. Paul dan Gibb, A. Julie, "Perencanaan Penggunaan Tanah dalam Pengantar Perencanaan Kota," Airlangga, Jakarta (1984).

[10] E. Budihardjo, "Tata Ruang Perkotaan," Alumni, Bandung (1997). 